\title{
Meningkatkan Hasil Belajar IPA Melalui Penerapan Metode Inkuiri Terbimbing
}

\section{Gede Sujana* \\ SDN 6 Tianyar, Karangasem, Indonesia}

A R T I C L E I N F O

Article history:

Received 19 August 2020

Received in revised form

30 September 2020

Accepted 10 October 2020

Available online 29

November 2020

\section{Kata Kunci:}

Metode inquri terbimbing,

hasil belajar

Keywords:

Guided inquri method,

learning outcomes

A B S T R A K

Penelitian tindakan kelas ini bertujuan untuk mengetahui pengaruh penerapan metode pembelajaran inquri terbimbing terhadap hasil belajar siswa kelas VI pada mata pelajaran ilmu pengetahuan alam (IPA). Penelitian tindakan kelas ini dilaksanakan di SD. Subjek penelitian tindakan kelas ini adalah siswa kelas VI SD dengan populasi 19 orang siswa, terdiri dari 7 orang siswa laki-laki dan 12 orang siswa perempuan. Pengambilan data dalam penelitian ini dilakukan dengan pemberian tes kepada siswa. Metode ini digunakan untuk mengevaluasi hasil belajar siswa. Analisis data menggunakan dua metode, yaitu analisis data statistik deskriptif dan deskriptif kuantitatif. Hasil penelitian menunjukkan hasil belajar siswa kelas VI pada mata pelajaran IPA, dengan metode inquiri terbimbing dapat ditingkatkan. Hal ini dapat dilihat berdasarkan hasil penelitian yang diperoleh dimana awalnya persentase ketuntasan siswa mencapai $68,16 \%$ dimana nilai ini masuk dalam kategori sedang. Pada siklus I ketuntasan siswa naik menjadi $74,74 \%$ masuk dalam kategori tinggi, dan pada siklus II ketuntasan siswa terus meningkat menjadi $86,32 \%$ dimana persentase ini masuk kategori sangat tinggi. Hasil penelitian tersebut menunjukkan bahwa penggunaan metode inquiri terbimbing pada siswa kelas VI SD pada materi IPA di semester ganjil dapat meningkatkan hasil belajar siswa.

\section{A B S T R A C T}

This classroom action research aims to determine the influence of the application of guided inquri learning method to the learning outcomes of grade VI students in natural science subjects (science). This classroom action research was carried out in Elementary School 6 Tianyar in the odd semester of the academic year 2017/2018. The subjects of this classroom action research are the sixth grade students of elementary school with a population of 19 students, consisting of 7 male students and 12 female students. The data collection in this research is done by giving the test to the students. This method is used to evaluate student learning outcomes. Data analysis using two methods, namely descriptive statistical data analysis and quantitative descriptive. The result of the research shows the result of the study of the sixth grade students in science subjects with guided inquiri method can be improved. This can be seen based on the research results obtained where initially the percentage of student completeness reached $68.16 \%$ where this value is included in the category of being. In the first cycle student completeness rose to $74.74 \%$ entered in the high category, and in cycle II student completeness continues to increase to $86.32 \%$ where this percentage is categorized very high. The results of this study indicate that the use of guided inquiri method in grade 6 students of SD Negeri 6 Tianyar on natural science subjects (science) materials in the odd semester can improve student learning outcomes 


\section{Pendahuluan}

Negara yang maju dapat dilihat dari kualitas sumber daya manusianya. Sumber daya manusia yang berkualitas dipandang dari tingkat pendidikan, akan tetapi banyak yang beranggapan bahwa pendidikan yang tinggi hanya akan membuang waktu dan uang sehingga banyak orang-orang yang memilih bekerja dengan tingkat pendidikan yang minim. Oleh karena itu dilakukan bebagai upaya untuk meningkatkan mutu pendidikan, supaya pandangan tersebut dapat dihapuskan.

Meningkatkan mutu pendidikan tidaklah mudah dan dapat dilakukan dengan instan, tetapi perlu upaya yang berkesinambungan serta pengelolaan yang sesuai. (Hamalik, 2005) menyatakan, bahwa diperlukan pengelolaan pendidikan yang mampu mewujudkan pendidikan yang bermutu, relevan dengan kebutuhan masyarakat, dan dapat berdaya saing tinggi dalam kehidupan global. Untuk mendukung hal tersebut, maka perlulah dilakukan tiga pembaharuan pendidikan utama yaitu : pembaharuan kurikulum, peningkatan kualitas pembelajaran, dan efektifitas metode pembelajaran (Nurhadi, 2003).

Pendidikan merupakan salah satu bidang yang mempunyai peranan besar dalam pembangunan di suatu negera selain bidang ekonomi, politik, keamanan, dan sebagainya. Maju mundurnya bangsa banyak ditentukan oleh maju mundurnya pendidikan, oleh karena itu pendidikan harus dilaksanakan sebaikbaiknya agar memperoleh hasil yang maksimal. Pendidikan di Indonesia masih tertinggal dari negara-negara lain, salah satu faktornya belum sadarnya masyarakat tentang pentingnya pendidikan dan dengan banyaknya siswa yang tidak melanjutkan ke jenjang pendidikan yang lebih tinggi, maka dari itu Pendidikan di Indonesia yang berakar pada kebudayaan bangsa berdasarkan Pancasila dan UndangUndang Dasar 1945 terus ditata, dikembangkan, dilengkapi berbagai ketentuan peraturan serta mengutamakan pemerataan dan peningkatan kualitas pendidikan. Upaya ini perlu didukung oleh sumber daya pendidikan secara bertahap disertai keterpaduan dan efisiensi pelaksanaannya sehingga mampu memenuhi tuntutan dan kebutuhan pembangunan di Indonesia (Firmansyah, 2015).

Ilmu pengetahuan alam (IPA) adalah salah satu mata pelajaran yang memiliki peran besar dalam meningkatkan pendidikan. Hal ini karena dalam mata pelajaran IPA siswa lebih banyak mengamati fenomena alam dan melakukan eksperimen dengan metode ilmiah. Oleh karena itu penggunaan metode yang tepat dalam proses pembelajaran haruslah benar-benar tepat dan sesuai. Mata pelajaran IPA memiliki keunikan dan karakteristik tersendiri yaitu : (1) proses belajar IPA hampir melibatkan semua indera, seluruh proses berfikir, dan berbagai macam gerakan otot; (2) belajar IPA dilakukan dengan menggunakan berbagai cara (teknik); (3) belajar IPAmemerlukan berbagai macam alat, terutama untuk membantu pengamatan. Hal ini dilakukan karena kemampuan alat indera manusia itu sangat terbatas; (4) belajar IPA seringkali melibatkan kegiatan-kegiatan temu ilmiah; (5) belajar IPA merupakan proses aktif.

Fakta dilapangan sangatlah berbeda, sebab banyak sekali siswa dalam proses pembelajarannya tidak sesuai dengan apa yang menjadi tujuan utama pendidikan. Sehingga banyak siswa yang tidak paham pada pembelajaran IPA, sehingga siswa banyak yang tidak mampu mencapai nilai kriteria ketuntasan minimal (KKM). Siswa cenderung menghafal materi pembelajaran tanpa mengetahui konsep dari meteri tersebut. Siswa juga kurang aktif dan kreatif dalam bereksperimen serta rasa keingintahuan siswa sangat rendah. Selain itu di kelas biasanya proses pembelajaran hanya terfokus pada guru saja. Hal inilah yang menjadi permasalahan utama dalam proses pembelajaran di kelas.

Untuk mengatasi hal tersebut, perlulah dilakukan suatu perubahan streategi pada proses belajar mengajar di kelas yaitu melalui pendekatan kontekstual. Salah satu caranya adalah dengan menerapkan metode pembelajaran inkuiri terbimbing. Metode inkuiri terbimbing merupakan penyajian pelajaran yang memberi kesepatan kepada peserta didik untuk menemukan informasi dengan atau tanpa bantuan guru sehungga dapat mencari dan menyelidiki masalah tersebut secara kritis dan logis (Asih \& Ibnu, 2018; Wati et al., 2018). Metode ini akan membuat peserta didik memiliki rasa keingintahuan (Hariyadi et al., 2016) yang tinggi sehingga mental siswa akan menjadi lebih tinggi dalam melakukan suatu eksperimen dengan penemuan sendiri, yang membuat siswa akan lebih paham terhadap konsep pembelajaran. Melalui inkuiri terbimbing siswa dapat mengalami sendiri proses pencarian fakta-fakta yang kemudian diuji, dievaluasi, dan digunakan untuk memecahkan masalah, dan dapat menemukan kemungkinankemungkinan jawaban dari permasalahan sehingga keterampilan berpikir kreatif siswa pun akan terlatih (Sintya et al., 2018). Pada model inkuiri terbimbing, peserta didik belajar berhipotesis sehingga peserta didik terdorong untuk berpikir dan bekerja atas inisiatifnya sendiri untuk menemukan konsep secara langsung (Harjilah et al., 2019; Hariyadi et al., 2016).

Beberapa hasil penelitian yang relevan dan mendukung terhadap penelitian yang dilakukan penulis yaitu : (1) penelitian oleh Ai Dasima,dkk yang berjudul "Pendekatan Inkuiri terbimbing Untuk Meningkatkan Hasil Belajar Siswa". Memaparkan bahwa hasil belajar dan kinerja guru dapat ditingkatkan dengan pendekatan inkuiri terbimbing. Hal ini dapat dilihat dari persentase ketuntasan nilai hasil belajar kognitif siswa pada siklus I (73,08\%), siklus II $(84,62 \%)$, dan siklus III $(88,46 \%)$. Persentase ketuntasan 
nilai hasil belajar afektif siswa pada siklus I (46,15\%), siklus II $(69,23 \%)$, dan siklus III $(80,77 \%)$. Persentase ketuntasan nilai hasil belajar psikomotor siswa pada siklus I (76,92\%), siklus II (80,77\%), dan siklus III $(88,46 \%)$. Sementara nilai kinerja guru pada siklus I (75), siklus II $(81,25)$, dan siklus III $(81,25)$. (2) penelitian oleh Rosita, dkk dengan judul "Meningkatkan Hasil Belajar Siswa Pada Mata Pelajaran IPA Melalui Metode Inkuiri Terbimbing Di Kelas IV SD Inpres 3 Terpencil Baina'a". Memaparkan Hasil penelitian I diperoleh tuntas individu 7 orang dan tidak tuntas individu 4 orang dengan persentase daya serap klasikal 73,19\% dan ketuntasan belajar klasikal 63,64\%. Hasil belajar siklus II satu siswa dinyatakan semua tuntas individu, diperoleh persentase yaitu $100 \%$ dengan persentase daya serap klasikal 86,59\%. Dengan demikian dapat disimpulkan bahwa penggunaan metode inkuiri terbimbing dapat meningkatkan hasil belajar siswa dalam pembelajaran IPA siswa kelas IV SD Inpres 3 Terpencil Baina'a. (3) penelitian oleh Marian, dkk dengan judul "Pembelajaran Inkuiri Terbimbing Untuk Meningkatkan Hasil Belajar Siswa Kelas XI IPA SMA Negeri 1 Teweh Timur Pada Materi Sistem Gerak". Memaparkan Hasil belajarsiswa pada siklus I diperoleh ketuntasan klasikal sebesar 74.00 meningkat menjadi 91,00 pada siklus II. Psikomotor siswa pada siklus I rata-rata sebesar 59,95 dengan kategori kurang meningkat pada siklus II dengan rata-rata 81,66 menjadi kategori sangat baik.Perilaku berkarakter siswa diperoleh rata-rata pada siklus I sebesar 65,62 dengan kategori cukup meningkat pada siklus II menjadi 82,29 dengan kategori sangat baik. Keterampilan sosial siswa pada siklus I sebesar 62,49 dengan kategori cukup meningkat menjadi kategori sangat baik pada siklus II dengan perolehan nilai sebesar 84,79. Aktivitas siswa dalam kegiatan pembelajaran siklus I diperoleh ratarata sebesar 59,81 dengan kategori cukup meningkat pada siklus II menjadi 82,96 dengan kategori sangat baik. Aktivitas guru dalam mengelola pembelajaran mengalami peningkatan dari siklus I diperoleh rata-rata 63,58dengan kategori cukup meningkatan pada siklus II menjadi 88,51 dengan kategori sangat baik. Siswa memberikan respon positif terhadap pembelajaran menggunakan model inkuiri terbimbing sebesar $91 \%$.

Penerapan metode inkuiri dalam pembelajaran IPA lebih banyak memberikan kesempatan kepada siswa untuk dapat menemukan sendiri, bukan hasil ingatan. Dengan demikian diharapkan hasil belajar siswa meningkat karena siswa tidak terfokus dengan hafalan tetapi sudah bereksperimen secara langsung. Berdasarkan hal tersebut dilakukanlah penelitian peningkatan hasil belajar IPA dengan metode inkuiri terbimbing. Tujuan penelitian ini adalah Meningkatkan Hasil Belajar IPA Melalui Penerapan Metode Inkuiri Terbimbing pada Siswa Kelas VI SD N 6 Tianyar Semester I Tahun Pelajaran 2017/2018.

\section{Metode}

Tindakan kelas ini termasuk penelitian kuantitatif. Penelitian Tindakan Kelas ini dilaksanakan pada semester I di SD N 6 Tianyar Tahun Pelajaran 2017/2018 dengan subjek penelitian siswa kelas VI. Jumlah siswa kelas VI SD N 6 Tianyar adalah 19 orang, laki-laki 7 orang dan perempuan 12 orang yang diambil secara random sampling. Objek penelitian penerapan metode inkuiri terbimbing pada pembelajaran IPA. Variabel terikat yang menjadi fokus perhatian dalam penelitian ini adalah hasil belajar IPA. Adapun perencanaan pelaksanaan penelitian tindakan kelas ini dimulai sejak bulan Juli 2017 sampai dengan bulan Desember 2017.

Penelitian ini dilaksanakan dalam 2 siklus. Tiap siklus terdiri atas empat tahap yaitu: (1) Perencanaan (planning) adalah mempersiapkan kebutuhan yang diperlukan untuk input instrumental dan persiapan perangkat PTK seperti RPP, LKS, Lembar evaluasi, dan format penilaian. (2) Tindakan (action) adalah pelaksanaan proses pembelajaran sesuai dengan fase-fase inkuiri seperti fase berhadapan dengan masalah, fase pengumpulan data penguji, fase pengumpulan data dalam eksperimen, fase formulasi penjelasan, dan fase analisis proses inkuiri. (3) Pengamatan (observation)/evaluasi adalah mengamati secara langsung proses pembelajaran yang berlangsung di kelas, apakah siswa diamati secara diskusi kelompok atau selama proses pembelajaran. Evaluasi adalah tes hasil belajar digunakan untuk mengetahui hasil belajar siswa pada mata pelajaran IPA. (4) Refleksi adalah mengkaji keseluruhan proses dan menetapkan hasil penelitian terhadap pelaksanaan tindakan tersebut dengan maksud jika terjadi hambatan kemudian, dipikirkan pemecahannya untuk direncakaan tindakan pada siklus berikutnya.

Untuk mengumpulkan data dalam penelitian ini digunakan metode tes berupa soal pilihan ganda. Hasil tes penelitian tindakan kelas ini berupa data mentah, yaitu data yang belum dianalisis. Data yang sudah dikumpulkan kemudian dianalisis dengan metode analisis statistik deskriptif dan metode deskriptif kuantitatif. (1) Metode Analisis Deskriptif adalah pengolahan data yang dilakukan dengan jalan menerapkan rumus-rumus statistik deskriptif seperti distribusi frekuensi, angka rata-rata (Mean) untuk menggambarkan keadaan suatu objek tertentu. Rumus-rumus yang digunakan dalam analisis data statistik deskriptif adalah sebagai berikut. 


$$
M=\frac{\Sigma X}{N}
$$

Keterangan:

$$
\begin{array}{ll}
\mathbf{M} & \text { : Mean } \\
\mathbf{\Sigma X} & \text { : Jumlah Skor seluruh siswa } \\
\mathbf{N} & \text { : Banyaknya Siswa }
\end{array}
$$

(2) Metode Deskriptif Kuantitatif adalah pengelolaan data yang dilakukan dalam bentuk angkaangka dan persentase mengenai obyek yang diteliti sehingga diperoleh kesimpulan umum. Adapun rumus yang digunakan untuk analisis ini sebagai berikut.

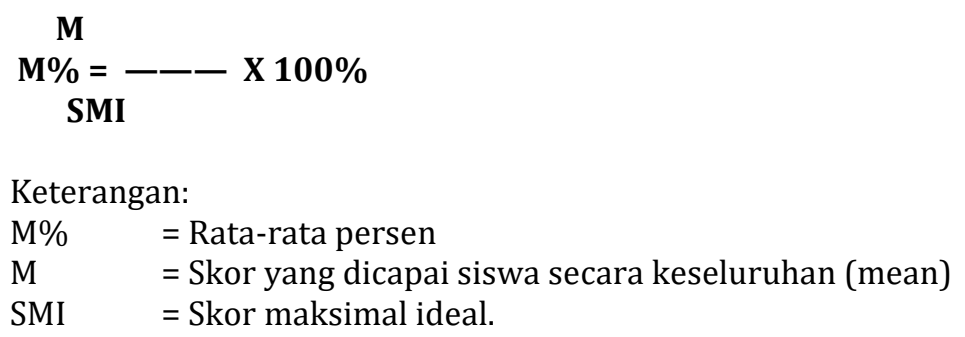

Adapun indikator keberhasilan penilaian dalam penelitian tindakan kelas ini yaitu dengan melihat hasil rekap nilai tes yang diberikan pada akhir siklus. Penelitian tindakan kelas ini dikatakan berhasil apabila rata-rata hasil belajar siswa mencapai 80,00 dengan ketuntasan belajar klaksikal minimal mencapai $80 \%$.

\section{Hasil dan Pembahasan} Tianyar.

Berdasarkan hasil penelitian, diperoleh peningkatan hasil belajar siswa kelas VI SD Negeri 6

Tabel 1 . Ringkasan data Hasil Belajar Siswa

\begin{tabular}{ccc}
\hline Tahapan & Persentase & Kriteria Hasil Belajar \\
\hline Refleksi Awal & $68,16 \%$ & Sedang \\
Siklus I & $74,74 \%$ & Tinggi \\
Siklus II & $86,32 \%$ & Sangat tinggi \\
\hline
\end{tabular}

Pada tabel 1,1 dapat dilihat bahwa dengan metode inkuiri terbimbing siswa mengalami peningkatan hasil belajar IPA. Pada siklus I peningkatan mencapai 6,58\% dari refleksi awal, dan pada siklus II peningkatan mencapai $18,16 \%$ dari refleksi awal.

Penelitian tindakan kelas ini dilalsanakan dalan 2 siklus. Data yang dikumpulkan dalam penelitian ini adalah data mengenai hasil belajar IPA siswa kelas VI semester I SD N 6 Tianyar tahun pelajaran 2017/2018. Rincian mengenai data tersebut dapat dijelaskan sebagai berikut.

\section{Hasil Penelitian siklus I}

Pada tahap ini, peneliti menyusun RPP penulis menentukan media dan instrumen pembelajaran seperti LKS dan soal-soal evaluasi.

Pada siklus I dilakukan 2 kali pertemuan, pada siklus ini dilaksanakan empat tahapan yaitu perencanaan, pelaksanaan, observasi, dan refleksi, dengan waktu pelaksanaan seperti pada tabel berikut :

Tabel 2. Jadwal pelaksanaan tindakan siklus I

\begin{tabular}{cccc}
\hline No. & Hari/Tanggal & Jam ke & Kegiatan \\
\hline 1 & Senin, 23-10-2017 & $6-7$ & Siklus I (Pertemuan1) \\
2 & Kamis, 26-10-2017 & $4-5$ & Siklus I (Pertemuan 2) \\
3 & Senin, 30-10-2017 & $6-7$ & Evaluasi Siklus I \\
\hline
\end{tabular}


Tes berupa pilihan ganda (objektif) yang berjumlah 20 butir yang diberikan oleh guru dilaksanakan pada hari senin, tanggal 30 Oktober 2017, dengan hasil pengamatan seperti tabel berikut.

Tabel 3. Skor Hasil Belajar Siswa Siklus I

\begin{tabular}{|c|c|c|c|}
\hline No & Kode siswa & Siklus I & Keterangan \\
\hline 1 & 001 & 60 & Belum Tuntas \\
\hline 2 & 002 & 65 & Belum Tuntas \\
\hline 3 & 003 & 70 & Tuntas \\
\hline 4 & 004 & 65 & Belum Tuntas \\
\hline 5 & 005 & 95 & Tuntas \\
\hline 6 & 006 & 90 & Tuntas \\
\hline 7 & 007 & 85 & Tuntas \\
\hline 8 & 008 & 70 & Tuntas \\
\hline 9 & 009 & 70 & Tuntas \\
\hline 10 & 010 & 70 & Tuntas \\
\hline 11 & 011 & 85 & Tuntas \\
\hline 12 & 012 & 65 & Belum Tuntas \\
\hline 13 & 013 & 80 & Tuntas \\
\hline 14 & 014 & 70 & Tuntas \\
\hline 15 & 015 & 80 & Tuntas \\
\hline 16 & 016 & 90 & Tuntas \\
\hline 17 & 017 & 75 & Tuntas \\
\hline 18 & 018 & 75 & Tuntas \\
\hline 19 & 019 & 60 & Belum Tuntas \\
\hline \multicolumn{2}{|c|}{ Jumlah } & 1,420 & \\
\hline \multicolumn{2}{|c|}{ Rata-Rata (Mean) } & 74,74 & \\
\hline \multicolumn{2}{|c|}{ KKM (Kriteria Ketuntasan Minimal) } & 70 & \\
\hline \multicolumn{2}{|c|}{ Jumlah Siswa yang Mesti Diremidi } & 5 & \\
\hline \multicolumn{4}{|c|}{ Jumlah Siswa yang Perlu Diberi } \\
\hline \multicolumn{2}{|c|}{ Pengayaan } & 14 & \\
\hline \multicolumn{2}{|c|}{ Prosentase Ketuntasan Belajar } & $73,68 \%$ & \\
\hline
\end{tabular}

Refleksi merupakan kajian secara menyeluruh tindakan yang telah dilakukan berdasarkan data yang telah terkumpul, kemudian dilakukan evaluasi guna penyempurnaan tindakan. Refleksi menyangkut analisis, sintesis, dan penilaian terhadap hasil pengamatan atas tindakan yang dilakukan.

Berdasarkan hasil belajar siswa untuk siklus I rata-rata persentase yang diperoleh yaitu $74,74 \%$ dengan kriteria hasil belajar siswa persentase berada pada 70\% - 84\% termasuk katagori tinggi. Dengan tingkat ketuntasan klaksikal mencapai 73,68\%. Hasil yang dicapai pada siklus I belum mencapai kondisi ideal karena masih ada 5 orang siswa yang memperoleh nilai di bawah KKM 70. Dan tingkat ketuntasan belajar secara klaksikal belum mencapai $\geq 80 \%$.

\section{Hasil Penelitian Siklus Ii}

Berdasarkan hasil refleksi siklus I, maka untuk siklus II disusun rencana perbaikan. Sebagai upaya perbaikan tindakan untuk siklus II. Perbaikan yang dilaksanakan untuk mengatasi kendala pada siklus I adalah meningkatkan bimbingan terhadap siswa yang masih bermasalah dalam mengerjakan tugasnya.

Tabel 4. Jadwal pertemuan siklus II

\begin{tabular}{cccc}
\hline No. & Hari/Tanggal & Jam ke & Kegiatan \\
\hline 1 & Senin, 13-11-2017 & $6-7$ & Siklus II (Pertemuan1) \\
2 & Kamis, 16-11-2017 & $4-5$ & Siklus II ( Pertemuan 2) \\
3 & Senin, 20-11-2017 & $6-7$ & Evaluasi Siklus II \\
\hline
\end{tabular}

Evaluasi yang digunakan adalah butir soal objektif berjumlah 20 butir yang harus dijawab oleh siswa dengan hasil sebagai berikut: 
sering didominasi oleh siswa yang pintar, 5) waktu belajar kurang efektif sehingga pembelajaran tidak optimal.

Berdasarkan implementasi rancangan pada siklus II yang merupakan perbaikan tindakan siklus I, memberikan peningkatan hasil yang signifikan dilihat dari peningkatan persentase hasil belajar. Hal tersebut disebabkan karena siswa sudah terbiasa mengikuti pembelajaran dengan menggukan metode inkuiri terbimbing. Pembelajaran dengan menggunakan metode inkuiri melatih siswa untuk menjawab dan menemukan sendri pemecahan masalah yang mereka hadapi.

Dari pemaparan di atas, secara umum telah mampu menjawab rumusan masalah. Peneliti dapat dikatakan berhasil karena semua kriteria terpenuhi. Metode inkuiri terbimbing merupakan penyajian pelajaran yang memberi kesepatan kepada peserta didik untuk menemukan informasi dengan atau tanpa bantuan guru sehungga dapat mencari dan menyelidiki masalah tersebut secara kritis dan logis (Asih \& Ibnu, 2018; Wati et al., 2018). Metode ini akan membuat peserta didik memiliki rasa keingintahuan (Hariyadi et al., 2016) yang tinggi sehingga mental siswa akan menjadi lebih tinggi dalam melakukan suatu eksperimen dengan penemuan sendiri, yang membuat siswa akan lebih paham terhadap konsep pembelajaran. Melalui inkuiri terbimbing siswa dapat mengalami sendiri proses pencarian fakta-fakta yang kemudian diuji, dievaluasi, dan digunakan untuk memecahkan masalah, dan dapat menemukan kemungkinan-kemungkinan jawaban dari permasalahan sehingga keterampilan berpikir kreatif siswa pun akan terlatih (Sintya et al., 2018). Pada model inkuiri terbimbing, peserta didik belajar berhipotesis sehingga peserta didik terdorong untuk berpikir dan bekerja atas inisiatifnya sendiri untuk menemukan konsep secara langsung (Harjilah et al., 2019; Hariyadi et al., 2016). Hal tersebut sesuai dengan Suastra (2009), menyatakan bahwa model pembelajaran inkuiri terbimbing adalah suatu strategi pembelajaran yang berpusat pada siswa dimana kelompok-kelompok siswa dihadapkan pada suatu persoalan atau mencari jawaban tethadap pertanyaan-pertanyaan melalui suatu prosedur yang direncanakan dengan jelas. Melalui kegiatan tersebut siswa mampu memahami berbagai konsep dan akan meningkatkan hasil belajar siswa.

Beberapa hasil penelitian yang relevan dan mendukung terhadap penelitian yang dilakukan penulis yaitu : (1) penelitian oleh Ai Dasima,dkk yang berjudul "Pendekatan Inkuiri terbimbing Untuk Meningkatkan Hasil Belajar Siswa". Memaparkan bahwa hasil belajar dan kinerja guru dapat ditingkatkan dengan pendekatan inkuiri terbimbing. Hal ini dapat dilihat dari persentase ketuntasan nilai hasil belajar kognitif siswa pada siklus I (73,08\%), siklus II $(84,62 \%)$, dan siklus III $(88,46 \%)$. Persentase ketuntasan nilai hasil belajar afektif siswa pada siklus I (46,15\%), siklus II (69,23\%), dan siklus III $(80,77 \%)$. Persentase ketuntasan nilai hasil belajar psikomotor siswa pada siklus I (76,92\%), siklus II $(80,77 \%)$, dan siklus III (88,46\%). Sementara nilai kinerja guru pada siklus I $(75)$, siklus II $(81,25)$, dan siklus III $(81,25)$. (2) penelitian oleh Rosita, dkk dengan judul "Meningkatkan Hasil Belajar Siswa Pada Mata Pelajaran IPA Melalui Metode Inkuiri Terbimbing Di Kelas IV SD Inpres 3 Terpencil Baina'a". Memaparkan Hasil penelitian I diperoleh tuntas individu 7 orang dan tidak tuntas individu 4 orang dengan persentase daya serap klasikal 73,19\% dan ketuntasan belajar klasikal 63,64\%. Hasil belajar siklus II satu siswa dinyatakan semua tuntas individu, diperoleh persentase yaitu 100\% dengan persentase daya serap klasikal 86,59\%. Dengan demikian dapat disimpulkan bahwa penggunaan metode inkuiri terbimbing dapat meningkatkan hasil belajar siswa dalam pembelajaran IPA siswa kelas IV SD Inpres 3 Terpencil Baina'a. (3) penelitian oleh Marian, dkk dengan judul "Pembelajaran Inkuiri Terbimbing Untuk Meningkatkan Hasil Belajar Siswa Kelas XI IPA SMA Negeri 1 Teweh Timur Pada Materi Sistem Gerak". Memaparkan Hasil belajarsiswa pada siklus I diperoleh ketuntasan klasikal sebesar 74.00 meningkat menjadi 91,00 pada siklus II. Psikomotor siswa pada siklus I rata-rata sebesar 59,95 dengan kategori kurang meningkat pada siklus II dengan rata-rata 81,66 menjadi kategori sangat baik.Perilaku berkarakter siswa diperoleh rata-rata pada siklus I sebesar 65,62 dengan kategori cukup meningkat pada siklus II menjadi 82,29 dengan kategori sangat baik. Keterampilan sosial siswa pada siklus I sebesar 62,49 dengan kategori cukup meningkat menjadi kategori sangat baik pada siklus II dengan perolehan nilai sebesar 84,79. Aktivitas siswa dalam kegiatan pembelajaran siklus I diperoleh ratarata sebesar 59,81 dengan kategori cukup meningkat pada siklus II menjadi 82,96 dengan kategori sangat baik. Aktivitas guru dalam mengelola pembelajaran mengalami peningkatan dari siklus I diperoleh rata-rata 63,58dengan kategori cukup meningkatan pada siklus II menjadi 88,51 dengan kategori sangat baik. Siswa memberikan respon positif terhadap pembelajaran menggunakan model inkuiri terbimbing sebesar 91\%.

\section{Simpulan dan Saran}

Penelitian ini menjelaskan melalui penerapan metode inkuiri terbimbing dapat meningkatkan hasil belajar pada mata pelajaran IPA siswa kelas VI semester I SD N 6 Tianyar tahun pelajaran 2017/2018. Hal 
ini dapat dilihat dari rata-rata awal 68,16\% naik menjadi 74,74\% pada siklus I, berada pada kriteria tingkat penguasaan 70\%-84\% dalam karegori tinggi. Sedangkan pada siklus II rata-rata hasil belajar IPA yaitu $86,32 \%$ berada pada kriteria tingkat penguasaan $85-100 \%$ dalam karegori sangat tinggi dan terjadi peningkatan 11,58\% dari siklus I. Dari data awal ketuntasan klasikal hasil belajar 57,89\% naik menjadi $73,68 \%$ pada siklus I dan pada siklus II naik menjadi 94,74\%. Berdasarkan hasil penelitian, dapat diajukan beberapa saran sebagai berikut diantaranya siswa agar lebih sering belajar dengan cara memecahkan masalah sendiri sehingga terbiasa berfikir kritis dan lebih sering belajar dengan menggunakan media alam sekitar dalam pembelajaran IPA, guru-guru sekolah dasar agar berusaha mencari informasi yang lebih banyak tentang cara mengaktifkan pembelajaran IPA dengan melibatkan siswa sebagai pusat pembelajaran.

\section{Daftar Rujukan}

Dasima, A., Latief, S., \& Mustakim, E. (2014). Pendekatan Inkuiri Terbimbing Untuk Meningkatkan Hasil Belajar Siswa. Jurnal Pedagogi, 2(1). http://dx.doi.org/10.17977/jp.v1i11.8127

Asih, F. E., \& Ibnu, S. (2018). Pengaruh Pembelajaran Inkuiri Terbimbing dengan Penyajian Representasi Submikroskopik yang Berbeda terhadap Pemahaman Konseptual Siswa pada Materi Sel Volta. Jurnal Pendidikan, 3(11), 1434-1439. https://doi.org/http://dx.doi.org/10.17977/jptpp.v3i11.11750

Firmansyah, Dani. Pengaruh Strategi Pembelajaran Dan Minat Belajar Terhadap Hasil Belajar Matematika . Jurnal Pendidikan Unsika Volume 3 Nomor 1, Maret 2015. https://journal.unsika.ac.id/index.php/judika/article/view/199

Hamalik, Oemar. (2008). Kurikulum dan Pembelajaran. Jakarta : PT. Bumi Aksara.

Hamalik, Oemar. 2005. Proses Belajar Mengajar. Jakarta : PT Bumi Aksara.

Hariyadi, D., Ibrohim, I., \& Rahayu, S. (2016). Pengaruh Model Pembelajaran Inkuiri Terbimbing Berbasis Lingkungan Terhadap Keterampilan Proses dan oenguasaan konsep IPA. Jurnal Pendidikan, 1(8), 1567-1574. https://doi.org/2502-471X

Harjilah, N., Medriati, R., \& Hamdani, D. (2019). Pengaruh Model Inkuiri Terbimbing Terhadap Keterampilan Berpikir Kritis Pada Mata Pelajaran Fisika. Jurnal Kumparan Fisika, 2(2), 79-84. https://doi.org/https://doi.org/10.33369/jkf.2.2.79-84

Nurhadi, dan Senduk, AG. 2003. Pembelajaran Kontekstual dan penerapannya dalam KBK. Malang: Universitas Negeri Malang. http://library.um.ac.id/freecontents/index.php/buku/detail/pembelajaran-kontekstual-contextual-teaching-and-learningctldan-penerapannya-dalam-kbk-oleh-nurhadi-burhan-yasin-agus-gerrard-senduk-28747.html

Rosita, dkk. Meningkatkan Hasil Belajar Siswa Pada Mata Pelajaran IPA Melalui Metode Inkuiri Terbimbing di Kelas IV SD Inpres 3 Terpencil Baina'a. Diakses 14 Juni 2017.

Sholichah, Aas Siti. 2018. Teori-Teori Pendidikan Dalam Al-Qur'an. Jurnal Edukasi Islami Jurnal Pendidikan Islam Vol. 07/No.1, April 2018. http://dx.doi.org/10.30868/ei.v7i01.209

Sintya, W. K., Purwanto, A., \& Sakti, I. (2018). Penerapan Model Pembelajaran Inkuiri Terbimbing Untuk Meningkatkan Kemampuan Berpikir Kreatif Siswa di SMAN 2 Kota Bengkulu. Jurnal Kumparan Fisika, 1(3). https://doi.org/https://doi.org/10.33369/jkf.1.3.7-12

Suastra, I W.2009. Pembelajaran Sains Terkini Mendekatkan Siswa Dengan Lingkungan Alamiah dan Sosial Budayanya. Singaraja: Universitas Pendidikan Ganesa Singaraja.

Sutrisno. 2016. Berbagai Pendekatan Dalam Pendidikan Nilai Dan Pendidikan Kewarganegaraan . Jurnal Dimensi Pendidikan dan Pembelajaran Vol.5 Januari 2016. DOI : 10.24269/dpp.v4i1.56

Wati, A., Susilo, H., \& Sutopo. (2018). Pengaruh Pembelajaran Inkuiri Terbimbing Berbantuan Jurnal Belajar terhadap Penguasaan Konsep IPA Siswa. Jurnal Pendidikan, 3(1), 129-133. https://doi.org/http://dx.doi.org/10.17977/jptpp.v3i1.10411

Widodo, Heri. 2015. Potret Pendidikan Di Indonesia Dan Kesiapannya Dalam Menghadapi Masyarakat Ekonomi Asia (Mea) . Jurnal Cendekia Vol. 13 No. 2, Juli - Desember 2015. https://doi.org/10.21154/cendekia.v13i2.250 